\title{
Quality control of distilled beverages
}

\author{
Alina SOCEANU, Simona DOBRINAS*, Viorica POPESCU and Florian MOISE \\ Department of Chemistry and Chemical Engineering, Ovidius University of Constanta, 124 Mamaia Blvd, \\ 900527 Constanta, Romania
}

\begin{abstract}
The aim of this research is to characterize some distilled drinks commercially available on the market (brandy, gin, vodka, whiskey) and some distilled beverages provided by private manufacturers (palinca made in copper, aluminum and stainless steel distillation apparatus). For this purpose the alcoholic concentration, the dry extract, the total acidity, the ash content and copper level were determined. The alcoholic concentration was measured using the picnometer method and the copper content was determined by UV-VIS molecular absorption spectrometric method. This study shows that the distilled beverages commercially available on the market can be discriminated from palinca, a homemade brandy using the differences between the obtained results.
\end{abstract}

Keywords: brandy, gin, vodka, whiskey, palinca, copper, UV-VIS

\section{Introduction}

Commercial distilled spirits constitute a complex mixture of some hundreds of flavor compounds in an ethanol-water matrix. Each compound has a flavor contribution that is determined by both its concentration and its unique sensory threshold value. This means that levels of the abundant compounds cannot be easily linked to perceived flavor, as the odor impact of low threshold trace compounds can often be more dominant [1].

Natural distilled alcoholic beverages could be obtained by alcoholic fermentation of fruit pulps or fermentation of wine's residues.

Several analytical methods for characterization of distilled drinks, such as liquid chromatography coupled with mass spectrometry followed by NMR spectroscopy [2], gas chromatography coupled with mass spectrometry [3] and capillary electrophoresis [4] have been published. Also, UV-VIS spectrometric methods were used for characterization of distilled drinks [5], while fluorescence spectroscopy offers a promising approach for the characterization of distillates [6].

The aim of this study was to characterize some commercially distilled drinks available on the market (brandy, gin, vodka, whiskey) and some distilled beverages provided by private manufacturers (palinca made in copper, aluminum and stainless steel distillation apparatus). For this purpose the alcoholic concentration, the dry extract, the total acidity, the ash and copper content were determined.

\section{Experimental}

\subsection{Samples}

The studied samples were some commercially distilled drinks available on the market (brandy, gin, vodka, whiskey) and some distilled beverages provided by private manufacturers (palinca made in copper, aluminum and stainless steel distillation apparatus). Palinca is a homemade brandy. 


\subsection{Sample analysis}

The alcoholic concentration was measured using the picnometer method. For the calculation of alcoholic concentration the relative density was determined and correlated with the alcoholic concentration values at $20^{\circ} \mathrm{C}$ expressed in $\%$ vol from tables.

The total dry extract or dry matter means all substances which, under given physical conditions, do not volatilize. Knowledge of dry extract of alcoholic beverages is important in commercial terms and in terms of counterfeiting when suspected counterfeit product with water, alcohol or sugar. The extract of the samples was obtained by evaporation of $5 \mathrm{~mL}$ sample to dryness in a sand bath. After evaporation capsule is inserted into the desiccator for 30 minutes to cool and then the residue is weighed on analytical balance.

The total acidity was determined by titration with $\mathrm{NaOH}$ in presence of phenolphtaleine after the removing of the $\mathrm{CO}_{2}$.

Determination of ash can be useful in detecting counterfeiting with sugar. Samples evaporated to dryness, were calcinated at $600^{\circ} \mathrm{C}$ for three hours. After that the samples were cooled 30 minutes in the desiccator and then weighed on analytical balance.

To determinate the copper concentration in studied samples, the standard addition method was used. Two solutions A and B have been prepared: solution A containing only unknown sample and solution B unknown sample and a measured volume of standard solution of $\mathrm{Cu}$ (II).

\section{Solution A:}

- in a $50 \mathrm{~mL}$ volumetric flask were added $5 \mathrm{~mL}$ of studied sample, $2.5 \mathrm{~mL}$ ammonia and were diluted to volume with distilled water;

- the absorbance was read at $600 \mathrm{~nm}$ on DR 2000 spectrometer reporting to a reference solution (distilled water).

\section{Solution B:}

- in another flask were added 5mL sample solution, $2 \mathrm{~mL}$ standard $\mathrm{Cu}$ (II) reagent and then were added to solution $\mathrm{A}$ in the presented order;

- the absorbance was read at $600 \mathrm{~nm}$ on DR 2000 spectrometer reporting to a reference solution (distilled water).

\section{Results and discussions}

The alcoholic concentration, the dry extract, the total acidity, the ash and copper content for some commercially distilled drinks available on the market (brandy, gin, vodka, whiskey) and some distilled beverages provided by private manufacturers (palinca made in copper, aluminum and stainless steel distillation apparatus) were determined.

The results are presented in Tables 1-4.

Palinca made in copper boiler has the higher alcoholic concentration $(51.73 \%$ vol.) than other analyzed distilled drinks (table 1).

Some values of alcoholic concentration for distilled drinks do not ranged in the limits imposed by the Law of vineyard and wine [7] for the Romanian distilled wine (minimum $36 \%$ vol.) and by SR 13442 [8].

Table 1. The values of alcoholic concentration in analyzed samples

\begin{tabular}{|c|c|}
\hline Distilled drinks & $\begin{array}{c}\text { Alcoholic } \\
\text { concentration } \\
\text { (\% vol. })\end{array}$ \\
\hline $\begin{array}{c}\text { Palinca stainless steel } \\
\text { distillation apparatus }\end{array}$ & 24.58 \\
\hline $\begin{array}{c}\text { Palinca aluminum } \\
\text { distillation apparatus }\end{array}$ & 30.02 \\
\hline $\begin{array}{c}\text { Palinca copper } \\
\text { distillation apparatus }\end{array}$ & 51.73 \\
\hline Palinca from market & 38.65 \\
\hline Whiskey & 26.99 \\
\hline Brandy & 31.96 \\
\hline Vodka & 27.99 \\
\hline Gin & 40.60 \\
\hline
\end{tabular}

Also, the Brandy do not respect the French normative which stipulate that the cognac has a minimum alcoholic concentration of $40 \%$ vol. when it's sold on the market [9].

For whiskey, the information provided by the manufacturer does not match with the experimental value, the difference being about 13 percent.

The highest value for extract was recorded (see table 2) for gin sample, indicating a possible forgery. Brandy (natural drink obtained from wine by distillation and aging) has a fairly large amount of extract $(1.14 \mathrm{~g} / \mathrm{L})$. The extract of this drink coming from wood barrels in which aging was performed 
and hence it varies in direct proportion to the period of aging. The higher extract value for market palinca is due to the addition of sugar, which is further specified on the label.

Table 2. The values of extract in analyzed samples

\begin{tabular}{|c|c|}
\hline Distilled drinks & $\begin{array}{c}\text { Extract } \\
\text { (g /L) }\end{array}$ \\
\hline $\begin{array}{c}\text { Palinca stainless steel } \\
\text { distillation apparatus }\end{array}$ & 0.42 \\
\hline $\begin{array}{c}\text { Palinca aluminum } \\
\text { distillation apparatus }\end{array}$ & 0.24 \\
\hline $\begin{array}{c}\text { Palinca copper } \\
\text { distillation apparatus }\end{array}$ & 0.66 \\
\hline Palinca from market & 1.12 \\
\hline Whiskey & 0.58 \\
\hline Brandy & 1.14 \\
\hline Vodka & 0.80 \\
\hline Gin & 2.80 \\
\hline
\end{tabular}

From table 3 there was observed that the lowest value of total acidity was registered for market palinca $(0.03 \mathrm{mg} / \mathrm{mL})$.

Whiskey and brandy could not be analyzed because of their color that interferes with the development of pink color.

Table 3. The values of total acidity in analyzed samples

\begin{tabular}{|c|c|}
\hline Distilled drinks & $\begin{array}{c}\text { Total acidity } \\
\text { (mg acetic acid } / 100 \mathrm{ml} \\
\text { ethylic alcohol anhydrous) }\end{array}$ \\
\hline $\begin{array}{c}\text { Palinca stainless steel } \\
\text { distillation apparatus }\end{array}$ & 0.175 \\
\hline $\begin{array}{c}\text { Palinca aluminum } \\
\text { distillation apparatus }\end{array}$ & 0.306 \\
\hline $\begin{array}{c}\text { Palinca copper } \\
\text { distillation apparatus }\end{array}$ & 0.042 \\
\hline Palinca from market & 0.030 \\
\hline Vodka & 0.007 \\
\hline Gin & 0.020 \\
\hline
\end{tabular}

During the first 3 years of ageing process the total acidity of distilled drinks increases, it decreases during the next six months and then increases again, as reported in literature [10].

The mineral substances contained in alcoholic beverages are assessed by weighing the residue distilled from calcination of samples at high temperatures. Determination of ash is useful in detecting counterfeit sugar.

The values for ash and copper content of studied samples are presented in table 4

Table 4. The values of ash and copper content in analyzed samples

\begin{tabular}{|c|c|c|}
\hline Distilled drinks & $\begin{array}{c}\text { Ash } \\
\text { content } \\
{[\%]}\end{array}$ & $\begin{array}{c}\text { Copper } \\
\text { Content } \\
{[\mathrm{mg} / \mathrm{L}]}\end{array}$ \\
\hline $\begin{array}{c}\text { Palinca stainless steel } \\
\text { distillation apparatus }\end{array}$ & 0.0207 & 0.017 \\
\hline $\begin{array}{c}\text { Palinca aluminum } \\
\text { distillation apparatus }\end{array}$ & 0.0480 & 0.017 \\
\hline $\begin{array}{c}\text { Palinca copper } \\
\text { distillation apparatus }\end{array}$ & 0.0520 & 0.098 \\
\hline Palinca from market & 0.0421 & 0.026 \\
\hline Whiskey & 0.0565 & 0.087 \\
\hline Brandy & 0.0479 & 0.050 \\
\hline Vodka & 0.0845 & 0.008 \\
\hline Gin & 0.0477 & 0.017 \\
\hline
\end{tabular}

One of the sources that can explain the copper presence in distilled liquors is the distillation apparatus. The samples were treated with sulfur dioxide, which is responsible for increasing copper concentration, leading to the deteriorating of the quality of distillate. The high value for palinca sample obtained in copper boiler is representative due to specific plant. In gin case, the value may reflect a treatment with sulfur dioxide. Copper concentrations reported for samples 1 and $2(0.017$ $\mathrm{mg} / \mathrm{L}$ ) lead to the conclusion that distillation process took place in stainless steel and not copper distillation apparatus, as expected. Research confirmed the conclusion of renowned manufacturers of distillates, obtained by long practice and careful observation: the essential role of copper in obtaining fine distillates, of very good quality.

\section{Conclusions}

Not all alcohol concentrations analyzed corresponds to the label's information.

For whiskey, the information provided by the manufacturer regarding alcoholic concentration does not match with the experimental value, the difference being about 13 percent. 
The lowest value of total acidity was registered for market palinca $(0.03 \mathrm{mg} / \mathrm{mL})$.

The high value for palinca sample obtained in copper distillation apparatus is representative due to the specificity of the plant.

\section{References}

* $\quad$ E-mail address: sdobrinas@ univ-ovidius.ro

[1]. K. N. Namara, R. Leardi and A. Sabuneti, Analytical Chimica Acta 542, 260 (2005)

[2] J.L. Puech, C. Mertz, V. Michon, C. Le

Guerneve, T. Doco and C. Herve du Penhoat, J. Agric. Food Chem. 47, 2060 (1999)

[3] J. Ledauphin, J.F. Saint-Clair, O. Lablanquie, H. Guichard, N. Founier, E. Guichard and D. Barillier, J. Agric. Food Chem 52, 5124 (2004)

[4] N. Oztechin and F.B. Erim, Turk J Chem 25, 145 (2001)
[5] M. Schwarz, M.C. Rodríguez, C. Martínez, V. Bosquet, D. Guillén and C. G.Barroso, Food Chemistry, in press

[6] J. Tóthová, L. Žiak and J. Sádecká, Acta Chimica Slovaca 1(1), 265 (2008)

[7] *** Vineyard and wine law into the common market organization in wine no. 244 (in Romanian) (2002)

[8]*** Standards Association of Romania (ASRO), SR 13442:1999. Spirits. Definitions. (in Romanian) [9] http://www.bnic.fr/cognac/_fr/2_cognac BNIC Bureau National Interprofessionnel du Cognac, Cognac fr - Tout sur le Cognac (2006)

[10] A. Popa, Production and aging of distilled from wine Publishing Romanian Writing (in Romanian), Craiova (1985)

Submitted: October $20^{\text {th }} 2012$ Accepted in revised form: November $1^{\text {st }} 2012$ 